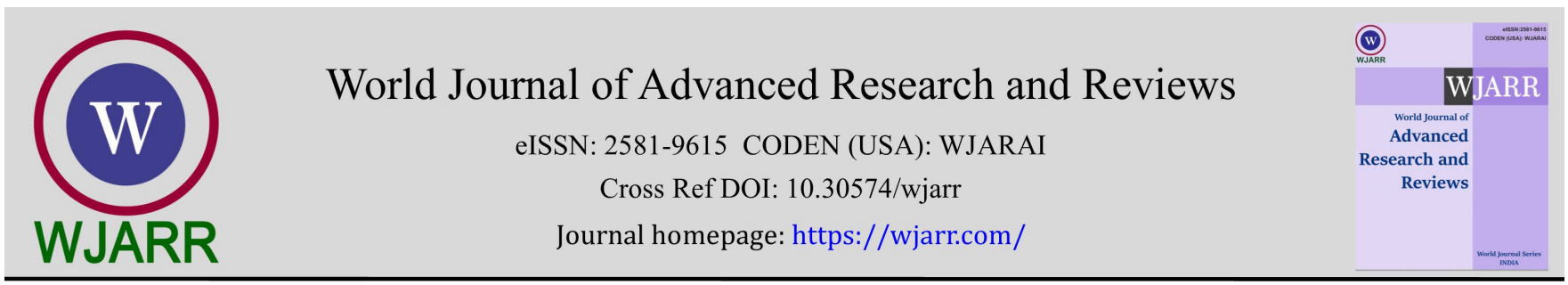

(REVIEW ARTICLE)

\title{
An evaluation of the role of engineering and infrastructure in national development
}

\author{
Agha Kalu Agwu *, Anikwe Nnaemeka J and Ogbonna Ndubuisi J \\ Department of Quantity Surveying, Akanu Ibiam Federal Polytechnic, Unwana Ebonyi State.
}

World Journal of Advanced Research and Reviews, 2021, 12(03), 602-611

Publication history: Received on 22 November 2021; revised on 29 December 2021; accepted on 31 December 2021

Article DOI: https://doi.org/10.30574/wjarr.2021.12.3.0737

\begin{abstract}
The clamour for engineering and infrastructure in national development in all spheres of development is more in the developed nations but the responsibility is no less for the developing economies/nations. A lot of effort has been made in sustaining engineering and infrastructural development in Nigeria; still there are more deficiencies in the formalization. Therefore this paper contributes to effort of formalizing the role it play in the national development. The sources of data were mainly on secondary source which rely on much of literature review and the analysis was analytical. The finding reveals the role of engineering and infrastructure in national development and its sustainability. It also state that institution should be established to set a clear plans and rule for service provision, regulate and monitor service quality, coordinate engineering and infrastructural project efficiently and equitably in maintenance of the existing infrastructure. The paper concludes that the government is encouraged to show more commitment to engineering and infrastructure development than ever. It also states that good quality engineering and infrastructure is necessary to avoid bottlenecks and services disruption and to support a range of importance activities in the economy. It was recommended that government should ensure that the standard and policies relating to infrastructural development are addressed and handled holistically. And that effective evaluation of contracts, consulting and construction services of the required professionals should be put in place for proper implementation.
\end{abstract}

Keywords: Development; Engineering; Infrastructure; National; Sustainability

\section{Introduction}

Critical to Nigeria's economic development is the engineering and infrastructural sector, which has long stood as a major driver to growth and essential solution in addressing the country's infrastructural deficiencies. Engineering and infrastructure are important for faster economic growth and alleviation of poverty in the country. The adequate engineering and infrastructure in the form of road and railway transport system, ports, power, airports and their efficient working is also needed for integration of the national economy with other economies of the world.

A distinguishing feature of engineering and infrastructure is that while the demand-supply gap in case of other factors can be met by importing some of them, the deficiency of engineering and infrastructure cannot be made through imports. Because locations-based the need for relevant development of its capacity in the domestic economy. For example, you cannot import power facility, roads, ports or railways as they have to be built up in the domestic economy.

Infrastructures are the basic physical and organizational structures needed for the operation of a society like industries, buildings, roads, bridges, health services, governance and so on as stated earlier. It is the enterprise or the product services and facilities necessary for an economy to function. Engineering and infrastructure can be described generally as the set of interconnected structural elements that provide framework supporting an entire structure development.

\footnotetext{
* Corresponding author: Agha Kalu Agwu

Department of Quantity Surveying, Akanu Ibiam Federal Polytechnic, Unwana Ebonyi State.

Copyright (C) 2021 Author(s) retain the copyright of this article. This article is published under the terms of the Creative Commons Attribution Liscense 4.0.
} 
It is the means of achieving an objective or set of objectives and also includes the objectives. It is an important term for judging a country, region or state's and individual's

Engineering and infrastructure can be used to refer to the technical structures that supports a society, such as roads, water supply, sewers, electrical national grids, telecommunications and so forth and can be defined as "the physical components of interrelated systems providing commodities and services essential to enable sustain or enhance societal living conditions" (Fulmer, 2009).

It is worthwhile to mention some distinctive features of engineering and infrastructure-first the building of infrastructure requires large and lumpy investment and they contribute to output, after a long time that is their gestation period is quite long. Second, due to large overhead capital and lumpy investment, the significant economies of scale are found in most of them. Due to the significant economies of scale found in many infrastructure services, they have the characteristics of natural money. The third important feature of engineering and infrastructure facilities is that they create externalities.

The functions of engineering and infrastructures includes the production of goods and services and also the distribution of finished products to end users (markets) as well as basic social services such as schools and hospitals. For example building of rural roads will benefit agriculture as the farmers are able to sell their products in towns where they can get remunerative prices. Besides they can also get inputs such as fertilizers, pesticides and other industrial products at relatively cheaper prices as their transport costs decline due to improved transportation. It is through engineering and infrastructure that power plants generate both positive and negative externalities. The construction of power plants produces electricity which is used for industrial helps production and commercial use and thereby helps in acceleration of economic growth. A power plant also produces negative externalities in the form of emission of pollutants, especially $\mathrm{CO}_{2}$.

The above feature of engineering and infrastructure means that competitive market system will not be able to achieve a socially optimal level of infrastructural services in most cases. Besides in many engineering and infrastructural facilities, there are significant economies of scale and therefore they have the features of natural monopoly. In other words, we find market failure to achieve their socially optimal level.

Therefore, these engineering and infrastructural facilities are either built or run by the government and public sector enterprises or if private sector is permitted to make investment in them and run them, they need to be regulated by the government, so that they should not exploit the consumers. For example, the distribution of electricity which is an infrastructural service is being provided by power holding company of Nigeria (PHCN), but the electricity rates and other charges are being regulated by an authority appointed by the government which is National Electricity Regulatory Commission (NERC). Similarly, in the telecommunication, which is another infrastructural services various companies such as Airtel, Globalcom, MTN etc are providing this services of wireless telephone (i.e. mobile services) are being regulated by the Nigerian Communication Commission (NCC).

There are two types of engineering infrastructure, "Hard and Soft" infrastructure. Hard refers to the large physical networks necessary for the functioning of a modern industrial nation, whereas "soft" infrastructure refers to all the institutions which are required to maintain the economic, health, and cultural and social standards of a country, such as the financial system, the education system, the health system, the governance system, and judiciary system, as well as security (Kumar, 2005). Engineers generally limit the use of the term infrastructure to describe fixed assets that are in the form of a large network, in other words, 'hard infrastructure'. The reality is that all the elements and components that make up an engineering infrastructure unavoidably, deteriorates with time due to inherent defects in design and construction, and the effects of environmental agents and users' activities. All engineering infrastructures are subject to aging, wear and tear in the performance of their functions and deterioration by exposure to outside operating environment. Hence, left to themselves, engineering infrastructures will eventually become inefficient, unreliable and fail. This report aims at the evaluation of engineering and infrastructure in national development. This is not limited to how the existing engineering infrastructure can be sustained but to the extent to which they are designed to perform will not be compromised.

The economy experienced Gross Domestic Product (GDP) growth Rate in Nigeria averaged 1.07 percent from 2010 until 2018 , reaching an unprecedented high of 10.59 percent in the third quarter of 2010 and a record low of -13.98 percent in the first quarter of 2016, this growth of 6.5 to 10.6 percent neither brings commensurate employment nor reduce the poverty level experienced in Nigeria. Nigeria is the biggest economy in Africa. An infrastructural service is the largest sector of the economy, accounting for about 50 percent of total GDP. One of the fastest growing segments in infrastructural services is Information and Communication, which together account for about 10 percent of the total 
output. Agriculture, which in the past was the biggest sector, now weights around 23 percent. Crude Petroleum and Natural Gas constitute only 11 percent of total GDP, while being the main exports. Industry and Construction account for the remaining 16 percent of GDP. This page provides - Nigeria GDP Annual Growth Rate - actual values, historical data, forecast, chart, statistics, economic calendar and news. Nigeria GDP Annual Growth Rate - actual data, historical chart and calendar of releases (TRE, 2018).

Nigeria's Gross Domestic Product (GDP) grew by 5.01\% (year-on-year) in real terms in the second quarter of 2021, marking three consecutive quarters of growth following the negative growth rates recorded in the second and third quarters of 2020. This is according to the recently published GDP report, released by the National Bureau of Statistics (NBS). The steady recovery observed since the end of 2020, with the gradual return of commercial activity as well as local and international travel, accounted for the significant increase in growth performance relative to the second quarter of 2020 when nationwide restrictions took effect. The non-oil sector grew by $6.74 \%$ in real terms while the oil sector declined by $12.65 \%$ year-on-year.

The contribution of the non-oil sector grew from 90.75\% recorded in the previous quarter to $92.58 \%$ in Q2 2021 while the oil sector contribution declined from $9.25 \%$ to $7.42 \%$.

Year to date, real GDP grew $2.70 \%$ in 2021 compared to $-2.18 \%$ for the first half of 2020 . Nevertheless, quarter on quarter, real GDP grew at $-0.79 \%$ in Q2 2021 compared to Q1 2021, reflecting slightly slower economic activity than the preceding quarter due largely to seasonality.

\section{Literature Review}

Infrastructures are basic essential services that should be put in place to enable development to occur. Socio-economic development can be facilitated and accelerated by the presence of social and economic infrastructures. If these facilities and services are not in place, development will be very difficult and in fact can be likened to a very scarce commodity that can only be secured at a very high price and cost. Olufemi, 2012 said that the challenges of infrastructure development in third world countries are mainly due to the fact that the demand surpasses the supply and finance that will stimulate rapid provision is not there. Due to this wide gap between provision and needs, the leadership classes are in arrears in all sectors. The political situation is not encouraging to foreign investors. Governments do not set the priority right in infrastructure development. Engineering projects are supposed to meet objectives, but in most cases, projects embarked upon are white elephant projects.

Good governance will be the only antidote that can bridge the wide gap. Secondly, good governance promotes accountability, reduces corruption and therefore minimizes resource wastage through inefficiency. And finally, good governance ensures stability (economic and political) and reduces the level of risk associated with large and lumpy infrastructure investments. This in turn facilitates the mobilization of both public and private sector financing resources that are critical for infrastructure development.

The geographical location of the country is very big with a large land mass which makes it impossible to spread out. Connecting the people of Nigeria with roads, National Grid and potable water will be tasking. High cost of materials for infrastructure development is also a challenge. The local content of production of goods and services must be increased to reduce production cost. Corruption level in Nigeria is too high and allows incompetent hands to handle contracts. Professionals are not allowed to handle projects due to corruption. The cost of governance and recurrent expenditure are so high leaving little for capital expenditure. The high level of unemployment is a dis-incentive to market and to capital development.

Owolabi et al. (2014) in their work "sustainability strategies in engineering infrastructure maintenance in developing countries: selected south western Nigeria states case study" found that sustainable approach to maintenance of engineering infrastructures could be achieved by implementing several parameters. Some of these parameters include;

- Introducing new construction design and maintenance concepts.

- Integrated approach in infrastructural design and construction.

- Empowering workers through knowledge base consolidation approaches such as: Seminars, Workshop, Vocational acquisition course, and Refresher course

- Clear communication of maintenance policy to all stakeholders.

- Incorporating eco-friendly construction material into building at building stage 
- Creating quality teams to oversee maintenance operations.

- Mechanization of production processes where necessary.

- Periodic retrospective check on process/success achieved at various policy and operations.

- Provision of good environment well ventilated workspace, first aid and protective items.

- Reengineering of building and maintenance process.

- Improvement of environmental standard in infrastructures construction and maintenance.

- Provision of incentives (financial and Non-financial)

Oyebode (2015) in his work established that construction of transport infrastructures plays an ever increasingly important role in the nation's drive for diversified economy that can lead to true sustainability. Apart from the industry's social-economic potentials, its employment generation capabilities and the multi-sectorial dimensions made it an area that a nation with vision can look into for sustainable development.

\subsection{Concept of Engineering and Infrastructural Sustainability}

A Sustainable infrastructure is viewed as the one that eliminates associated negative impact of infrastructures on user and environment. Various views exist when it comes to the definition of sustainability concept; one of such view is the sustainable design/construction. This school of thought maintains that it is the design of and construction of infrastructure in a way that will enable the present generation meet their needs without compromising the prospect of future generation in meeting their needs. Sustainable design/construction can also be described as the proper use of land, minimization of waste water, the use of less mechanical energy, understanding the site ecology, the application of eco-effective and recyclable materials among others (Solomon ,2005; Vijervaberg, 2000). This can be generally described as producing a high-performance infrastructure. Another school of thought views sustainable concept from the perspective of eliminating associated negative impact of infrastructure on users and environment, this school of thought emphasize maintaining infrastructure form and structure. Vijervaberg (2000) belong to this school of thought, that it is a design and construction practices that significantly reduce or eliminate the negative impact of building/infrastructures on the environment. It was established that this is achievable from the following six (6) key areas:

- Bioclimatic design indoor-environmental quality.

- Construction of materials and resources.

- Energy efficiency and renewable energy.

- Community design and connections; and sustainable design

A third school of thought believes that sustainable infrastructure should benefit society at large, improves standard of living (socially financially and economically), and secures the users health and safe for habitation. (Solomon, 2005; Vijervaberg, 2000).

\subsection{The Role of Engineers in National Economy}

The American Engineers' Council for Professional Development defines Engineering as: "The creative application of scientific principles to design or develop structures, machines, apparatus, or manufacturing processes, or works utilizing them singly or in combination; or to construct or operate the same with full cognizance of their design; or to forecast their behaviour under specific operating conditions; all as respects an intended function, economics of operation and safety to life and property."

One who practices engineering is called an engineer. Engineers borrow from physics and mathematics to find suitable solutions to the problem at hand. They engineers design, create, explore and innovate. They engineers receive formal education and training in many different fields and also work in many different environments. They engineers do things that make the world worthy of living.

The engineering profession makes important contributions to the economy, both from the direct addition to economic output from the work they do, and the contribution of the sectors in which they work. One can also consider the long run return to the economy of improvements in physical infrastructure, in which engineers have played a vital role, and the contributions engineers make to the knowledge economy and to sustainability.

Technology and innovation, this has played a vital role in the following area: 


\subsubsection{Education}

There has been a quality education with modern day's technology.

Many developed countries balance and sustain their economy with returns from their institutions and colleges

\subsubsection{Efficient Production}

Production of goods has been multiplied with less human effort, low cost, and improved qualities.

\subsubsection{Information Communication and Technology}

The rapid growth in ICT and Telecommunication has open doors of opportunities, and in turn boost the economy.

\subsubsection{Infrastructure}

The huge investment in Engineering in Nigeria and other developing countries like Dubai makes it a must go area for luxurious lovers.

\subsubsection{Development/Construction}

The Engineers deal with the creation, improvement, and protection of the environment, providing facilities for living, industry and transportation, including large buildings, roads, bridges, canals, railroad lines, airports, water-supply systems, dams, irrigation, harbours, docks, aqueducts, tunnels, and other engineered constructions within a given region which produces high economic values.

\subsubsection{Clean, Sustainable Energy}

Power plays a huge role in any other developments that happen to a country. Stable and sustainable power; stable and sustainable economy.

\subsection{Engineering Economics}

Engineering economics, previously known as engineering economy, is a subset of economics concerned with the use and "...application of economic principles" in the analysis of engineering decisions. It gets familiar with project management Costing, Accounting and learn all the rudiment of economic development. Engineers personal Development must include leadership and preparation for participation in National politics. This is where decision makers and policy that affects National economy are made. The Era of Engineers sitting back as advisers and consultants is fading.

\subsection{Engineers and Politics}

Involvements of Engineers in politics afford them the opportunity to be at these policy/decision making bodies. Engineers at these levels, use their professional knowledge to attract and defend important engineering infrastructural development projects. Similarly, Engineers in politics contribute to the enhancement of the welfare of other Engineers thereby motivating them to higher productivity for national economy development.

Engineering is the bedrock for development of any serious Nation. Just like China that has fifteen (15) high policy makers, nine (9) are Engineers. You and I know the level where China is today in terms of world power and National Economy Development.

\subsection{Concept of Sustainable Infrastructure}

\subsubsection{Green growth}

Green Growth is an approach to pursuing the economic growth necessary for pressure on the environment's limited carrying capacity, by improving the eco-efficiency of the society as a whole (Na and Raksakulthai, 2006). The international financing organizations like World Bank, IMF, etc, have reported Nigeria to be growing macroeconomically in the last few years. However, this pace of economic growth is placing increasing pressure on the ecological carrying capacity of the nation. More worrying is the limited focus of the Nigerian government to sustainable development. Now the challenge for nation is how to progress its economic growth and poverty reduction, while ensuring environmental sustainability. A shift towards environmentally sustainable economic growth or "Green Growth" would be necessary to continue economic growth while maintaining environmental sustainability. 


\subsubsection{Eco-efficiency}

Eco-efficiency is achieved by the delivery of competitively priced goods and services that satisfy human needs and bring quality of life, while progressively reducing ecological impacts and resource intensity throughout the life cycle to a level at least in line with the earth's estimated carrying capacity (World Business Council on Sustainable Development, 2013). It is often expressed as the creation of more value with fewer resources and less impact, or doing more with less. Many developing countries are now undergoing a process of designing their infrastructure and laying the foundation for their consumption and production patterns and, it is the optimum moment for these countries to apply and integrate ecoefficiency into their infrastructure development, consumption patterns, and production patterns (Na and Raksakulthai, 2006).

\subsubsection{Infrastructure}

Infrastructure is normally viewed as the physical assets that are defined as fundamental facilities and systems serving country, city, or area, as transportation and communication systems, power plants, and schools (Na and Raksakulthai, 2006; Oyedele, 2012). Infrastructure as a concept of sustainable development advocates the provision of necessary infrastructure as a means of sustaining developmental strives. The development of infrastructure is one of the main drivers of growth in an economy (Adenikinju, 2005).

Infrastructure systems such as water supply and sanitation, solid waste and wastewater, power, and transport form the backbone of the economy (Familoni, 2000) as they provide social as well as economic benefits to the people. It is admissible that infrastructure could achieve economic and/or social development. Familoni (2000) corroborated this and stated that socio-economic development can be facilitated and accelerated by the presence of social and economic infrastructures. However, the environmental aspects should not be compromised for the sake of the first two objectives. In order to achieve sustainability, decision makers must inculcate policies on infrastructure development that would conform to environmental protection policies. The infrastructure policies must enable increase in the efficiency of resource use to obtain more from less and reduce waste. This is the advocacy of sustainable infrastructure development, a concept of sustainable development.

\subsection{State of Infrastructure Development in Nigeria}

The role of infrastructure in contributing to economic development is an essential one. Good quality infrastructure is necessary to avoid bottlenecks and service disruptions and to support a range of important activities in the economy (Na and Raksakulthai, 2006). Akinwale (2010) used Brett Frischmann's 'Economic Theory of Infrastructure and Commons Management' of 2005 to describe infrastructure. The theory argues that 'certain important resources should equitably be used for the benefits of all members of a society'. Unfortunately, the Nigerian infrastructure is merger and efforts to improve them have not yielded the desired results (Akinwale, 2010). This implies that the Nigerian infrastructure situation sharply contrasts the 'Economic Theory of Infrastructure and Commons Management' of 2005. This infrastructure situation in Nigeria becomes more worrying due to the increased demand and limited resources. Oyedele (2012) expressed this fear that demand for infrastructural development is higher and resources used in provision of infrastructure are limited. The provision of infrastructure in most developing countries is the responsibility of the government (Adenikinju, 2005). Nigeria, with a very good share of Military government, has the era characterized by economic boom and only succeeded in widening the gap in infrastructure demand and provision. The current situation now is that most infrastructures are now decayed and needed repair or replacement (Oyedele, 2012). Adenikinju (2005) in a study analyzed the cost of power infrastructure inadequacy to the business sector of the Nigerian economy and a strong outcome of the study was that the poor state of electricity supply in Nigeria has imposed significant costs on the business sector of the Nigerian economy. The bulk of these costs were in the form of acquisition of very expensive backup power. Suffice to say that these power backups in form of petroleum and diesel driven generators that emits carbon (IV) oxide (CO2) causing the blockage of human lungs when inhaled and also contributes to the depletion of the ozone layer. Oyedele (2012) equates the infrastructure development of Nigeria with other developing economies but a critical analysis conducted by Akinwale (2010) reveals that Nigeria rates lower than countries like South Africa and even some low income countries in areas of power, road and telecommunication, water, health and disposal infrastructures. A critique analysis of Nigeria's infrastructure cutting across physical infrastructure (power, transport, oil and gas) and social infrastructure (health, education, water and sanitation) was conducted by Olaseni and Alade (2012).

\subsection{Importance of Infrastructure to National Development}

It needs to be emphasized that good quality infrastructure is important not only for faster economic growth but also to ensure inclusive growth. By inclusive growth we mean that benefits of growth are shared by the majority of the people of a country. Thus this inclusive growth will lead to the alleviation of poverty and reduction in income inequality in the 
country. For example, micro small and medium enterprises (MSME) are dispersed throughout the economy and production by them and their growth requires access to quality and reliable infrastructure services to compete efficiently with large scale enterprises which can often build some of their own infrastructure such as installing their own small power plants or generators. Besides large scale firms can even locate themselves near ports and near transport hubs where required infrastructure is available. Small enterprises on the other hand are dispersed widely in the economy and have to rely on the availability of the general infrastructure facilities. Thus, by building up general infrastructure facilities helps the small enterprises to compete successfully with large scale industries and being labour intensive generate large employment opportunities for the workers. This will help to alleviate the poverty in developing countries.

The expansion in infrastructure facilities such as irrigation, rural electrification, roads and road transport will promote agricultural growth and setting up of agro-processing industries. These general infrastructure facilities will help farmers and owners of processing industries to get their requirements of raw materials, fertilizers and other inputs at cheap rate and also help them to bring their products to the markets which are located in big towns and cities.

Thus according to Thirlwall," for poor farmers improved infrastructure will reduce their input cost and increase agricultural production and reduce traders monopoly by improving their access to markets. Nearly two thirds of African farmers are cut off from national and world markets, because of poor infrastructure and market access. Better transport means greater access to public resources including schools, hospitals and other health facilities'.

It follows from above that the expansion of infrastructure facilities will ensure sustained growth of employment in agriculture and small scale rural industries and bring property in the rural areas and in the way to ensure inclusive growth. Beside, this will also help to prevent the mass exodus of the rural people to urban areas where they cause problems of urban congestion growth of slums and acute housing shortage. Lack of adequate infrastructure not only holds lack economic development, it also causes additional cost in terms of time, effort and money of the people for accessing essential social services such as healthcare and education. Emphasizing the importance of adequate infrastructure, authors of economic survey of India for the year 2013-2014 quite rightly write, ; Rural economic growth in recent years has put enormous pressure on existing infrastructure particularly on transport, energy and communication. Unless it is significantly improved infrastructure will continue to be a bottleneck for growth and obstacle to poverty reduction", in other words, it is the challenge to ensure strong, sustainable and balanced development through integration of the economy with environmentally sustainable development in infrastructure.

\section{Research Methodology}

The research adopts a qualitative research approach. Yin (2009) reiterates that qualitative research focuses on contemporary events. This paper aim to evaluate the role of engineering and infrastructure in national development. Therefore the paper was grounded in extensive literature review on global best practices in sustaining infrastructure development. The findings were interpreted to in light of the experiences of the authors in the Nigerian engineering and infrastructure development. The interpretation of the synergy of both literature review and authors' experience was contextualised to reflect the peculiarity of the nation's environment. The approach used here is similar to Adelakun (2009) who sought to develop an understanding of the need for emerging economies like Nigeria to make use of strategic alliances by carrying out extensive literature review to gather data upon which recommendations were made.

\section{Results and discussion}

Since the research adopts qualitative approach, a lot of literatures were reviewed to draw inference on the result and to generate proper conclusion and recommendation. On this the following sub-tittles were reviewed as the result:

\subsection{Approaches to Sustaining Engineering and infrastructure in nation Development}

Sustainable engineering and infrastructure development has evolved as a paradigm to balance the developmental needs of man and to ensure that economic development is achieved without compromise to the environment and with due respect to delicate social balance (Lordos, et al, 2011). Therefore the clamour for engineering and infrastructural sustainability in all spheres of development is more in the developed economies. However, this responsibility is no less important for developing countries like Nigeria, given a number of factors, such as: rapid urbanization, decay of infrastructures, heavy regulation, little growth in productivity with chronic budget deficits or improper channelization of the budgets, a preoccupation with meeting the needs of the present by all means, with resulting environmental degradation and exploitation (Odedairo et al., 2011). Engineering and infrastructure has a significant impact on sustainability, and promoting environmentally sustainable and eco-efficient infrastructure are important goals that 
must be pursued not only in developing economies, but globally. Insights from the existing level of infrastructure development in Nigeria and global practices inform the following proposed means of ensuring sustainable infrastructure development in Nigeria.

\subsubsection{Institutionalization}

Fadare (2010) reiterate that legal and institutional policy framework is a response to environmental problem in Nigeria. Institutionalization is the process of setting up of capacities in form of public parastatals backed by appropriate laws to oversee the tendencies towards sustainable development and by extension; sustainable engineering and infrastructural development (Boxenbaum, 2010). These institutions should establish clear plans and rules for service provision, regulate and monitor service quality, coordinate engineering and infrastructure project development and deliver services efficiently and equitably both in the maintenance of the infrastructure. Just like the Nigerian Society of engineers who serve as a regulatory body in engineering profession. The body should be strengthened by the existing government to monitor all there infrastructural project both the existing structure, proposed ones and its maintenance. Within this mandate, these institutions must be managed professionally, open to public scrutiny, and accountable to the end users. These institutions should be strengthened to provide sustainable infrastructure through economic, financial, legal, and institutional reforms as well as adopting eco-efficient practices in management and provision. The scope of such institutions should incorporate both growth and sustainability over the long-term in order to achieve eco-efficient infrastructure and green growth. In Nigeria, the Federal and States Ministry of works and Environment have been saddled with most responsibility towards the engineering infrastructural sustainable development.

\subsubsection{Private sector participation}

The Nigerian government is encouraged to continually pursue the avenue of private sector participation in infrastructure development. It is noteworthy to point out that in the past year; concerted efforts have been noticed on the part of the Nigerian governments (States and Federal) in allowing for the private sector expertise in power projects across the country. This is very encouraging as the private sector becomes the driving force or the engine of development and growth of the power sector while the government's role is reduced to that of a catalyst responsible for the creation of an enabling environment. This way, government can concentrate on other areas of the economy and the private sector is left to give total attention to the concerned area of infrastructure development. This approach is nothing but a means to sustaining power infrastructure development in Nigeria. Privatization and commercialization strategy is a latter-day form of the classical laissez - faire policy or strategy of development. The concept embraces deregulation of the economy so as to encourage private initiative and boost productivity and efficiency. This would enable the governments of developing economies like Nigeria to reduce their public expenditures, generate more revenue and balance their budgets. The disposal of the economic infrastructures and parastatals would enable the government to focus more attention to and fund more adequately the social parastatals and infrastructures that create substantial external economies through the provision of public goods such as health, education, sanitation and portable water (Familoni, 2000).

\subsubsection{International Community Participation}

The international community can also contribute to sustainable engineering and infrastructure by supporting the implementation of best practices in infrastructure management as well as promoting sustainable development initiatives. Since 1983, engineering and infrastructural sustainable development has been a global agenda. It is one of the few areas where the global community voices in unity. For the developing economies, rather than pursue the cause of engineering and infrastructure development, the limited resources is better expended on more pressing issues. In this case, engineering and infrastructure development is seen not as of primary concern, which is a gross mistake. Thoughts and acts along this line is only a matter of time that it will come biting harder and, with graver consequences. However, the need for the international community participation in ensuring engineering and infrastructure sustainable development cannot be overemphasized. Apart from the fact that engineering and infrastructure development is a subject of utmost interest in the international community, a lot of breakthroughs in form of research and development have been made, as well as the required resources that will definitely benefit the sustainability tendencies of the developing economies. Government of the developing nations like Nigeria should show commitment to engineering and infrastructure development that is sustainable in all areas. The enabling environment where the international community can operate is thus advocated to ensure a successful working relationship with the government.

\subsubsection{Public Sector Commitment}

The nucleus of engineering and infrastructure development globally is the government. Most of the other approaches towards infrastructural development are either wholly or partially dependent on the government. Government plays a 
dominant role in level of sustainability that will be inculcated in her developmental strives. For engineering and infrastructure development, the public sector must strengthen the provision of sustainable infrastructure through economic, financial, legal, and institutional reforms as well as adopting eco-efficient practices in management and provision. In similar manner, $\mathrm{Na}$ and Raksakulthai (2006) stress that governments can stimulate progress in infrastructure sustainability by enacting legislative, financial, and technical measures to create the right incentives for innovation and changes in performance. In Nigeria and as stated earlier, it is important that the autonomy of the local government be granted. This way, the responsibility of ensuring sustainable development can be reposed on the local governments; as done globally.

\subsubsection{Stakeholder Participation (Civil Societies and Construction Professionals)}

The intertwining roles of various stakeholders such as construction professionals and civil societies are essential in the development and management of engineering and infrastructure development (Steurer, et al, 2005). In the contemporary times, stakeholder participation is an important consideration in most social phenomenon such sustainable infrastructural development. Stakeholders help define service requirements and the prioritization of infrastructure projects that will deliver these services. It is thus the best for any government to consult with diverse groups of residents, business leaders, local government leaders, civic organizations, and technical experts. Participation contributes to better-conceived projects and facilitates resolution of the inevitable conflicts that arise in every complex infrastructure project.

\section{Conclusion}

Good quality engineering and infrastructure is necessary to avoid bottlenecks and service disruptions and to support a range of important activities in the economy. It must also be recognised that the economic role and significance of infrastructure should not be accorded precedence over the other dimensions of sustainable development- the social, cultural, and environmental aspects. Impacts of engineering and infrastructure on these aspects of well-being are equally important, and the positive contribution that well-conceived infrastructure can make to improve other dimensions of sustainability is also vital. The intertwining roles of various stakeholders such as the government, international organizations, NGOs, civil society groups, and the private sector are essential in the development and management of sustainable engineering and infrastructure development in the nation's economies. The Nigerian government is encouraged to show more commitment to engineering and infrastructure development than ever. The role of the government of any nation is indispensable and more importantly, other approaches of engineering and infrastructural development depends on the level of commitment shown by government. Other actors like the international organisation, civil societies and the private sector are implored not to give up on their efforts towards an infrastructure development that can be called real and sustainable.

Engineering personnel and other man power base of infrastructural development needs to be consolidated through driving qualitative personnel, innovative and development programme. It is also necessary for the nation's development to be geared towards infrastructures that will have fewer operating cost through increasing productivity and using less energy and water; improved public and occupant health due to improved indoor air quality and reduced environmental impacts. However, huge cost is always involved in infrastructure maintenance. Engineering infrastructures are required in all aspects of human endeavour, they are found at various stages of human economic and social economic life, buildings are common one around, it as well includes road, dam, equipment in building, production structures, drainage facilities waste disposal and processing facilities, materials production units, health facilities, transportation units, electricity outfits and telecommunication systems. Development, resources, engineering and infrastructural standards and measurements must be considered in order to ensure national development.

\section{Compliance with ethical standards}

\section{Disclosure of conflict of interest}

No conflict of interest.

\section{References}

[1] Adelakun A. Enhancing Nigerian competitiveness in the global economy though strategic alliances. Economics and Management. 2009; 14: 649-554. 
[2] Adenikinju A. Analysis of the cost of infrastructure failures in a developing economy: The case of the electricity sector in Nigeria. African Economic Research Consortium Research000 Paper 148, Nairobi, Kenya. 2005.

[3] Akinwale AA. The Menace of Inadequate Infrastructure in Nigeria. African Journal of Science, Technology, Innovation and Development. 2010; 2(3): 207-228.

[4] Boxenbaum E. Innovation in Sustainable Construction: Eco-Cities and Social Housing in France and Denmark.

[5] CBN. Real Sector Developments; Central Banks of NigeriaAnnual Reports. 2012

[6] Fadare SO. Man, Environment and Technological Interface. A lead paper presented at the 1st international conference of the School of Environmental Technology, Federal University of Technology, Akure, Nigeria held at the SET Premises on 27th of October 2010.

[7] Familoni kA. The Role of Economic and Social Infrastructure in Economic Development: A Global View. 2000.

[8] Kumar D. Infrastructure in India. ICFAI Journal of Infrastructure. 2005.

[9] Lordos A, Sonan S, Solar A. Navigating the Paradigm Shift: Challenges and opportunities for the two communities of Cyprus, in the search for sustainable patterns of economic and social development. A report by the Cyprus 2015 initiative.

[10] Na JK, Raksakulthai V. Sustainable Infrastructure in Asia. Overview and Proceedings at the Seoul Initiative Policy Forum on Sustainable Infrastructure Seoul, Republic of Korea, 6-8 September 2006.

[11] Odedairo BO, Oke MO, Oyalowo BA. Achieving Sustainable Infrastructural Development in Developing Nations: Project Management Education to the Rescue. Management Science and Engineering. 2007; 5(4): 7-15.

[12] Olaseni M, Alade W. Vision 20:2020 and the Challenges of Infrastructural Development in Nigeria. Journal of Sustainable Development. 2012; 5(2): 63-76.

[13] Olufemi AO. The Challenges of Infrastructure Development in Democratic Governance. 2012.

[14] Owolabi D, Amusan LM, Ogunde A, Tunji-Olayeni P. Civil and Environmental Research. 2014; 6(2).

[15] Oxford Advanced learner Dictionary Sustainable. 2013.

[16] Oyedele OA. The Challenges of Infrastructure Development in Democratic Governance. A paper presented at the FIG Working Week with theme 'Knowing to manage the territory, protect the environment, evaluate the cultural heritage' held in Rome, Italy, 6th-10th of May 2012.

[17] Oyebode OJ. August 2015; 5(4):, -2015 International Journal of Engineering and Management Research ISSN (ONLINE): 2250-0758, ISSN (PRINT): 2394-6962

[18] Solomon N. The Pick of the Sustainable Crop", Architectural Record. 2005; 160.

[19] Steurer R, Langer ME, Konrad A, Martinuzzi A. Corporations, Stakeholders and Sustainable Development I: A Theoretical Exploration of Business-Society Relations. Journal of Business Ethics. 2005; 61: 263-281.

[20] Trading Economics Report (TRE, 2018).

[21] Vijervaberg G. "Busing Maintenance Needs on Accommodation Policy": Building Research and Information. 28CD. 2000; 18-25.

[22] Wikipedia. Sustainability. 2013.

[23] World Business Council for Sustainable Development. 2013.

[24] Yin RK. Case Study Research: Design and Methods. California; Sage publications. 2009. 